Fifth International Conference on Sustainable Construction Materials and

Technologies. http://www.claisse.info/Proceedings.htm

SCMT5

Kingston University London, UK, 14-17 July 2019

\title{
EFFECT OF DEGREE OF REFINING ON FLEXURAL RESPONSE OF FIBRE CEMENT BOARDS REINFORCED WITH GUADUA ANGUSTIFOLIA KUNTH BAMBOO.
}

\author{
Luz Adriana Sánchez Echeverri*1,2, Jorge Alberto Medina Perilla ${ }^{1}$, Germán \\ Quintana $^{3}$, Jorge Hernán Sánchez Toro ${ }^{3}$, Eshmaiel Ganjian ${ }^{4}$
}

\begin{abstract}
${ }^{1}$ Department of Mechanical Engineering, Universidad de los Andes, COLOMBIA. (E-mail: se.luz10@uniandes.edu.co,jmedina@uniandes.edu.co)

${ }^{2}$ Facultad de Ciencias básicas, NATURATU research group, Universidad de Ibagué, COLOMBIA. (E-mail: luz.sanchez@unibague.edu.co)

${ }^{3}$ Pulp and Paper research group, Faculty of Chemical Engineering, Universidad Pontificia Bolivariana, COLOMBIA (E-mail: german.quintana@upb.edu.co; jorgeh.sanchez@upb.edu.co)

${ }^{4}$ Built \& Natural Environment Research Centre, Faculty of Engineering \& Computing, Sir John Laing Building, Coventry University, UNITED KINGDOM (E-mail: E.ganjian@ coventry.ac.uk)
\end{abstract}

\begin{abstract}
In this research, alkaline pre-treated Guadua Angustifolia fibres were refined in a PFI mill refiner at different speeds (1500, 4500, 7000 and 10000 rev) and used as reinforcement in cement composite boards CCB. To determine physical changes after refining, Water Retention Value (WRV), Fibre length and SEM images were evaluated. Additionally, crystalline indices were calculated by Segal method from XRD spectra. With the aim to evaluate the effect of degree of refining in the mechanical response of CCB its flexural strength was evaluated after 7 and 28 days of curing. Results show an increasing of WRV up to $4500 \mathrm{rev}$ of refining, followed by a decrease once this point of refining is overcome. Likewise, flexural strength of composites shows a similar behaviour as WRV, exhibiting an optimal value between 4500 and $7000 \mathrm{rev}$ of refining
\end{abstract}

Keywords: Refining, Flexural response, Cement board composites.

\section{INTRODUCTION}

Climate change is a severe threat to human development. Environmental protection and economic growth are two significant dimensions of promoting sustainable global development. In those two dimensions, construction industry plays a significant role due to 
SCMT5

Kingston University London, UK, 14-17 July 2019

the large scale of resources used, including water, energy and materials. Building industry needs to assume the responsibility to contribute to sustainable development by finding more environmentally ways for construction. The searching for new materials that have a balance between resistance, appearance, handling, and costs with environmental impact has increased substantially in the last decades (Bissoli-Dalvi, Nico-Rodrigues, Alvarez, Saelzer Fuica, \& Montarroyos, 2016; Indraratna et al., 2015; Mohamad Bohari et al., 2015; Todd, Crawley, Geissler, \& Lindsey, 2001). Construction industry has opted for new types of materials, which have more advantages over traditional building materials in terms of costs and environmental impacts. Some of those materials are known as fibre reinforcement cement (FRC), which are very firm panels formed by cement slurry reinforced with fibres.

Recent works about fibre reinforcement cement have evaluated the mechanical behaviour of vegetable fibre; and they have demonstrated that these fibres have similar effects like synthetic fibres. Some of those effects are reduction of shrinkage, improvement of mechanical properties, reduction of porosity among others (Juarez et al., 2015; Santos, Tonoli, Mejia, Fiorelli, \& Jr, 2015). Due to these characteristics, fibres obtained from lignocellulosic materials have being increasingly used as reinforcement in cement-based materials in low cost construction in most developing countries (Agopyan, Savastano, John, \& Cincotto, 2005; Almeida, Tonoli, Santos, \& Savastano, 2013; Tonoli et al., 2009). In order to obtain cement composite with better characteristics, researchers have demonstrated that fibres need to be modified chemical or physically before being used as reinforcement to improve fibre-matrix bonding, mechanical properties and durability of the composites (Filho, Silva, \& Toledo Filho, 2013; Mohan \& Kanny, 2012; Sawsen, Fouzia, Mohamed, \& Moussa, 2015; Tonoli et al., 2013).

Kraft is one of the most used chemical treatments to modify fibres; this treatment is frequently combined with other mechanical treatments such as refining to enhance the physical bonds. Refining or beating is the most used mechanical treatment to improve strength properties it is usually performed in a water medium, where fibres are treated with metallic bars with configurations according to specific refiner designs. The PFI mill refiner whose name derivate from Norwegian Pulp and Paper Research Institute, is the most commonly used laboratory refiner, it is a higher energy and low intensity refining device (Gharehkhani et al., 2015). In this refiner, fibres are refining between stainless steel roll with bar and rotating disk with a smooth bed where fibres are distributed. Mechanical refining causes fibrillation, shortening, swelling, and surface modification on pulp fibres (Gao, Xiang, Chen, Yang, \& Yang, 2015; Gharehkhani et al., 2015). Those refining effects modify fibre properties and could affect its behaviour in cement matrix and so on in flexural strength of cement composite boards.

Some researchers have shown the effect of refining fibres in the mechanical response of cement based materials; however, no research can be found how PFI mill speed in the refining process affect the mechanical response of products reinforced with Guadua Angustifolia Kunth (bamboo) pulp fibres. Effects of Guadua pulp refining on the structural, morphological and physical changes of the fibre have not been systematically examined. This would lead to a better understanding of the mechanisms that affect the performance of 


\section{SCMT5}

Kingston University London, UK, 14-17 July 2019

fibre-cement materials produced by slurry dewatering. For this reason, this work addresses the influence of refining degree and their effects on the microstructure, physical and morphological changes in Guadua fibers and their relationship with mechanical properties of fibre-cement composites with the aim to attempt to produce a viable fibre-cement material.

\section{MATERIALS AND EXPERIMENTAL PROCEDURE}

\subsection{Materials}

Guadua Angustifolia Kunth's internodes taken from culm middle part (basa) were used to obtain fibres by alkaline treatment of $\mathrm{NaOH}$ and $\mathrm{Na}_{2} \mathrm{~S}$. Ordinary Portland cement (OPC) Type I was used for manufacturing of cement composites boards.

\subsection{Fibre Treatments and Composite Manufacture}

\subsection{Alkaline treatment}

Guadua chips (50mm x 20mm x 20mm) were milled in a blade mill and pass through a 0.23 $\mathrm{mm}$ Packer screen. Then they were subjected to alkaline treatment with the conditions describe in the Table 1.

Table 1. Parameters for delignification treatment in Guadua Angustifolia KUNTH

\begin{tabular}{l|c}
\multicolumn{1}{c|}{ Parameter } & Value \\
\hline *Active Alkali $\left(\mathrm{as} \mathrm{Na}_{2} \mathrm{O}\right)$ & $30 \%$ \\
$*$ Sulphidity $\left(\mathrm{as} \mathrm{Na}_{2} \mathrm{O}\right)$ & $30 \%$ \\
Liquor/fibre ratio & $5: 1$ \\
Cooking Temperature & $125^{\circ} \mathrm{C}$ \\
Pressure & $1.25 \mathrm{KPa}$ \\
Digestion Time & 45 min to reach Temperature -120 min cook
\end{tabular}

*by weight

After delignification treatment, fibres were washed with tap water for 15 minutes in order to remove chemical compound.

\subsubsection{Refining mechanical treatment}

The PFI mill basically consists of a rotor, a refining housing with lid and a device to apply pressure during the refining as is shown in Figure 1. The rotor and the housing rotate on a vertical axis. The number of rotor revolutions is indicated by a counter and is fixed by the user. 
SCMT5

Kingston University London, UK, 14-17 July 2019 a)

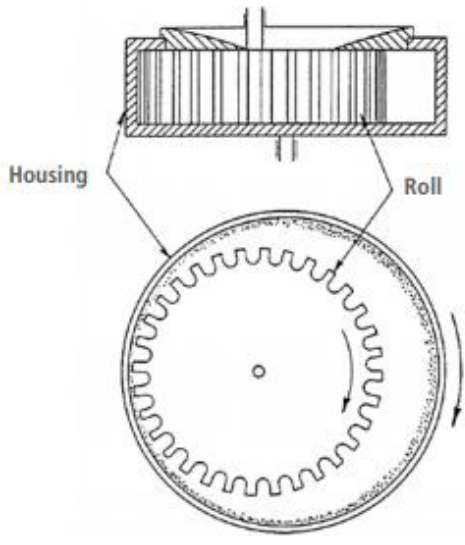

b)

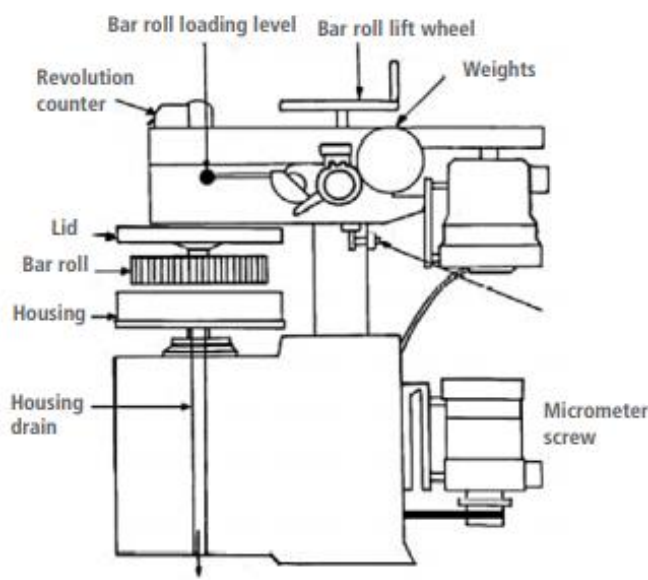

Figure 1. a) main elements of PFI mill b) Diagram of the PFI mill cross-section (Taken from Physical and Chemical Standards Committee (1971))

For refining process $30 \mathrm{~g}$ of alkali treated fibres were soaked in deionized water to obtain $10 \%$ consistency, and subsequently refined to 5 different levels of revolutions per minute $(0$, 1500, 4500, 7000 and 10000) in a PFI mill following Tappi Test Method T 248 sp-00.

\subsubsection{Manufacturing of Cement Composites Board}

$450 \mathrm{ml}$ of water and $130 \mathrm{~g}$ of Portland Cement Type I and a mass fraction of 5\% of refined Guadua fibre were mixed with to manufacture cement composite boards (CCB). CCB were prepared by a slurry vacuum de-watering technique in a slab shape with $200 \mathrm{~mm}$ length and $100 \mathrm{~mm}$ width. Once the board is formed they are demolding and cured in humidity (95\%) and $25^{\circ} \mathrm{C}$ temperature controlled. Kraft unrefined fibres was used to produce cement boards as a control in the same manner described before.

\subsection{Fibre Characterization}

\subsubsection{Fibre Length}

The length of alkaline treated pulp fibres was measure in different beating levels using the Tappi Test Method T 232 om-01. The length of non-refined fibres was also measured in order to have a comparison. $l$ is the length of any fibre in a sample and total length (L) of $\mathrm{N}$ fibres are measured and calculated using following equation: A total of 200 fibres were measured per each sample.

$$
L=\frac{\sum l}{N}
$$

\subsubsection{Water Retention Value (WRV)}

$0.18 \mathrm{~g}$ Oven Drye (O.D) basis of refined and non-refined fibre was soaked with $20 \mathrm{ml}$ water. 


\section{SCMT5}

Kingston University London, UK, 14-17 July 2019

The fibre pad was divided into three centrifuge tubes having $60 \mathrm{~mm}$ mesh. Tubes were placed into centrifuge during $15 \mathrm{~min}$ at $3000 \mathrm{rpm}$, at $25^{\circ} \mathrm{C}$. Thereafter, the pulp was weighed $\left(\mathrm{W}_{\text {wet }}\right)$ and oven-dried to $105^{\circ} \mathrm{C} \pm 2{ }^{\circ} \mathrm{C}$ for $24 \mathrm{~h}$, after this time pulp was reweighed ( $\left.\mathrm{W}_{\text {dry }}\right)$ and WRV was calculated using equation 1.

$$
(W R V)=\frac{W_{w e t}-W_{d r y}}{W_{\text {wet }}} \times 100 \%
$$

\subsubsection{SEM Images}

Fibre surface micrographies were taken by a scanning electron microscope (JEOL JSM$6490 \mathrm{LV}$ ) with a resolution of $5 \mathrm{~nm}$ in Low Voltage mode. Samples were stuck on a carbon adhesive after being covered with a gold film in order to make them conductive. The analysis conditions used $15 \mathrm{kV}$ electron acceleration voltages and 12-20 $\mathrm{Pa}$ of pressure using backscattering electron signal.

\subsubsection{X-Ray diffraction - Crystalline indexes}

$\mathrm{X}$-ray Diffraction patterns were recorded by Rigaku Ultima III, operating at $40 \mathrm{Kv}$ and $40 \mathrm{~mA}$, with $\mathrm{Cu} \mathrm{K} \alpha$ radiation wavelength of $\lambda=1.5406 \AA$. Data was collected from $10^{\circ}$ to $50^{\circ}$ on a $2 \theta$ scale with a step size of $0.05 \mathrm{~s}$. The measurements were made at room temperature and software JADE 9.0 was used for patterns identification. The crystallinity indices (CI) were calculated according to the Segal empirical method (Segal, Jr Creely, Martin, \& Conrad, 1959).

\subsection{Composite Characterization}

\subsubsection{Flexural Strength}

The 3 point loads flexural test was performed according to BS EN 12467:2012 in JJ Lloyd tensile testing machine. Specimens were tested after 7 and 28 days of curing. The thickness of the specimens was measured at 4 different spots, and the average was used to obtain modulus of rupture (MOR).

\section{RESULTS AND DISCUSSIONS}

\subsection{Wet Pulp Characterization}

The Beating process allows changes in structure and morphology properties of fibres, those changes are related with fibre swelling, fibre shortening, internal and external fibrillation (Gao et al., 2015). In this work, the evaluation of the refining effects on fibres are addressed in two ways: physical and structural.

\subsubsection{Fibre length}

The refining process produces the fine formation result of external fibrillation or fibre shortening. Fines consist of fragments of primary and secondary walls with sizes of less than $0.3 \mathrm{~mm}$ (Gharehkhani et al., 2015). Fines formation tend to be more intense as PFI mill speed 
SCMT5

Kingston University London, UK, 14-17 July 2019

increases. Figure 2 shows the fibre length changes for alkali treated fibres due to PFI mill speeds. After $4500 \mathrm{rpm}$ in the refining process, the fibre length has changed from $3.5 \mathrm{~mm}$ to $1.02 \mathrm{~mm}$; however, continuing to increase the speed has no considerable effect on fibres shortening that it is in accordance with previous works (Beg \& Pickering, 2008; Jones, Venditti, Park, Jameel, \& Koo, 2013).

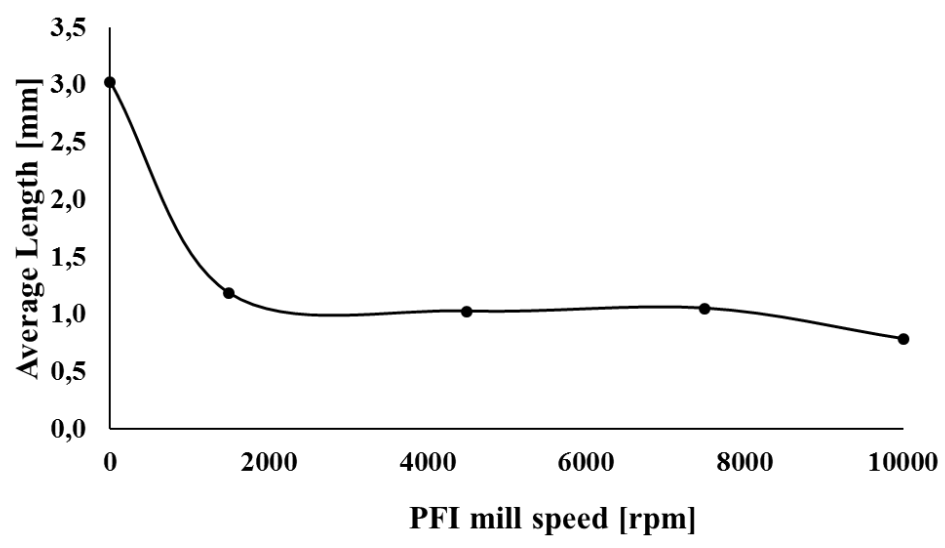

Figure 2. Changes in length of alkali treated fibres due to PFI mill different beating speeds.

\subsubsection{Water Retention Value (WRV)}

Figure 3 shows the variation of water retention value WRV due to beating speeds in the refining process. WRV is measured to identify the degree of fibre swelling. This measure is also related to total internal pore, fibril surface area, and enzymatic accessibility (Luo \& Zhu J.Y, 2011). The fibrillation due to the refining process results in the breakage of inner bonds which are between cellulosic fibrils, between fibrils and hemicellulose, between cellulose and lignin, and between hemicellulose and lignin. The bond rupture causes the pore structure inside the cell wall to expand and swell (Gharehkhani et al., 2015). This swelling capacity is observed in the WRV results, where it sharply increases for 4500 PFI mill revolutions per minute compared with non-refining fibre from $76 \%$ to $87 \%$ between 4500 and 7500 . There is a rise with a very low slope and then the behaviour suddenly changes for the last PFI mill revolution analysed (Figure 3). Wai et al. claimed the bamboo swells towards the outside of the cell wall and they emphasized that the internal fibrillation dispreads more rapidly in bamboo than in wood pulps (Wai, Nanko, \& Murakami, 1985). High fibrillation produces S1 delaminated layers during refining and they are major restraints against swelling due to their hydrophobic nature and the high fibril angle (Gharehkhani et al., 2015). This, could explain the change in trend behaviour for WRV after 4500 PFI mill revolutions per minute. 


\section{SCMT5}

Kingston University London, UK, 14-17 July 2019

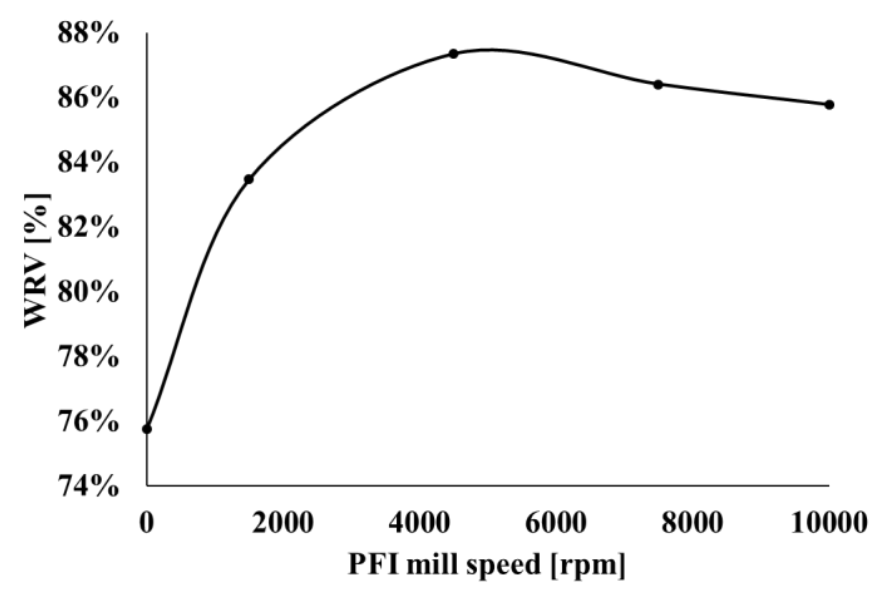

Figure 3. Changes in water retention value (WRV) for alkali treated fibres due to PFI mill different beating speed.

\subsubsection{X-ray Diffraction - Crystalline Indexes}

Figure 4 shows the diffraction patterns of treated fibres refined at 0, 150, 4500, 7500 and 10000 PFI mill speeds. All fibre samples exhibit a sharp high peak around 22-23, which is assigned to the $\left(\begin{array}{lll}0 & 0 & 2\end{array}\right)$ lattice plane of cellulose I. Although changes were observed in fibre surface SEM images, no significant changes in XRD data are observed, as is shown in Figure 3. It is possible to see a slight left shift in the main peak on XRD spectra of refined fibres attributed to differences in sample geometry as had been reported by (Tonoli et al., 2012).

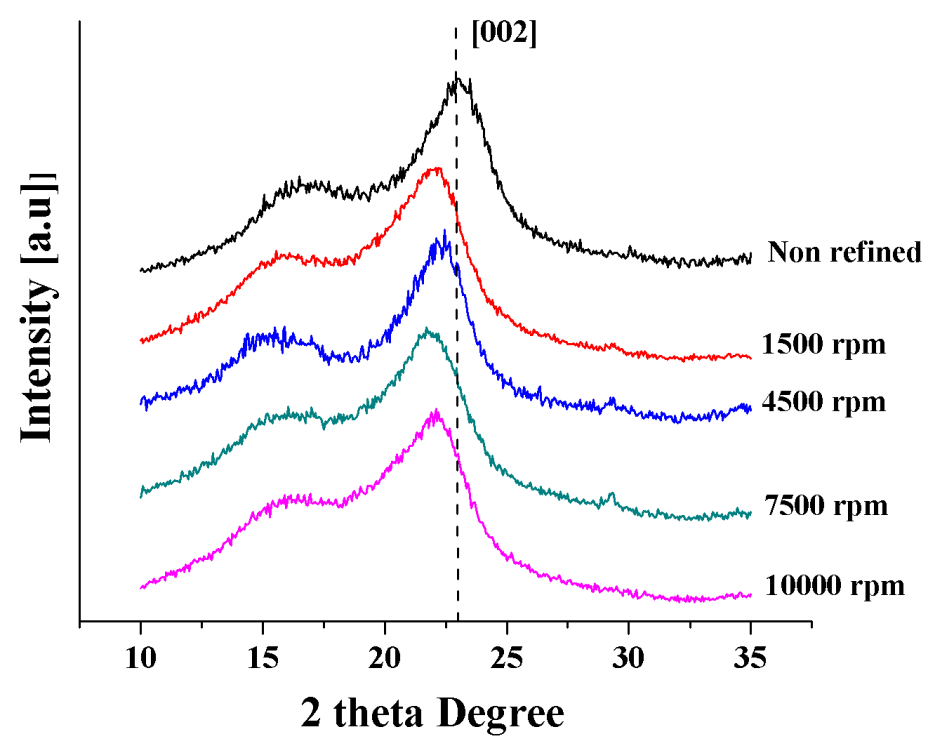

Figure 4. X-Ray diffraction patterns of alkali treated fibres to different refining speeds. 


\section{SCMT5}

Kingston University London, UK, 14-17 July 2019

Crystalline indexes $(\mathrm{CI})$ calculated by the empirical Segal method showed that the CI increased from 54\% up to 68\% with increased PFI mill sped up to 4500rpm; however, for greater PFI mill revolutions per minute, the CI decreased. During refining, fibres suffer shear forces, causing delamination and fibrillation on the fibre surface as was observed in SEM and optical images. Such effects imply that changes in hydrogen bonded structures change crystallinity (Yuan et al., 2013). Changes in crystallinity cause an increase in tensile strength and stiffness and a decrease in chemical reaction and swelling (Chen, Wan, Zhang, Ma, \& Wang, 2012).

Chen, et al., (2012) stated that the refining process has two states in crystallinity effect. In the first phase, amorphous regions of cellulose are influenced by the forces and it produces that an increment crystallinity of cellulose; however, in the later phase of refining the crystalline regions of cellulose are subjected to the force, thereby the crystallinity decreases. Finally, Gharehkhani et al. claimed that crystallinity is sensitive to degree of refining, and an increase or decrease in refining time or revolutions per minute will change the results.

\subsubsection{SEM Images}

SEM images were taken. Figure 5 shows SEM images of fibres after the refining process at 500 magnifications, white arrows represent the fibrillation due to the refining process. SEM images shows cleaned fibre surface compared with natural fibre without delignification treatment; it means fibre without waxes and oils (Ferreira, Silva, Lima, \& Toledo Filho, 2015; Mohan \& Kanny, 2012). In Figure 5a it is possible to see that the surface of the nonrefining fibre doesn't appear fibrillated (white arrows); however, as refining speed increase fibrillation appear (white arrows). For the two last speeds 7500 and 10000; it is possible that fibres form clusters and agglomerates (Figure 5d and 5e). 


\section{SCMT5}

Kingston University London, UK, 14-17 July 2019
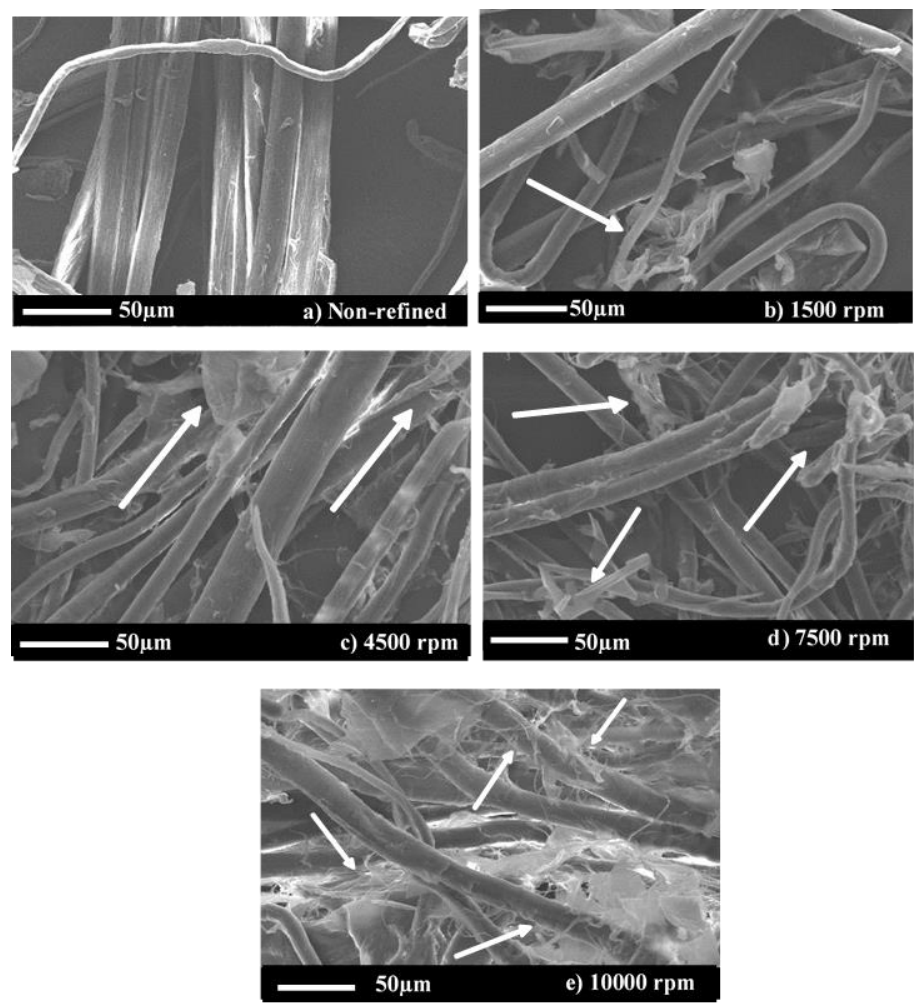

Figure 5. SEM images at 500X of fibre refined with different beating speeds a) $0 \mathrm{rpm} \mathrm{b}$ ) $1500 \mathrm{rpm} \mathrm{c)} 4500 \mathrm{rpm} \mathrm{d}) 7500 \mathrm{rpm}$ and e) $10000 \mathrm{rpm}$

\subsection{Cement Composite Boards Characterization}

\subsubsection{Flexural Strength}

The Flexural strength (FS) at 7 and 28 days of composites prepared with refined fibre are presented in Figure 6. FS increased from 5.33 up to $7.99 \mathrm{MPa}$ at 7 days and 7.68 up to 10.28 at 28 days with increased PFI mill speed up to 4500rpm, which could be due to the improvement of interfacial bonding between the fibre and the matrix resulting from the formation of micro fibrils and increased surface area. FS then decreased upon greater PFI mill speed, probably due to fibre damage. Beg and Pickering (2008) reported similar results in Kraft-polypropylene composites (Beg \& Pickering, 2008).

Another effect produced by internal fibre fibrillation is that the fibre becomes more flexible and collapsible, causing a closer contact which leads to strong bonding (Rusu, Mörseburg, Gregersen, Yamakawa, \& Liukkonen, 2011). This, strong bonding allows cluster formation which block cement grain distributions and affect cement hydration, causing less mechanical response as is shown for fibres refined above 4500 PFI mill revolutions per minute. A slight reduction of flexural response is observed. 
SCMT5

Kingston University London, UK, 14-17 July 2019

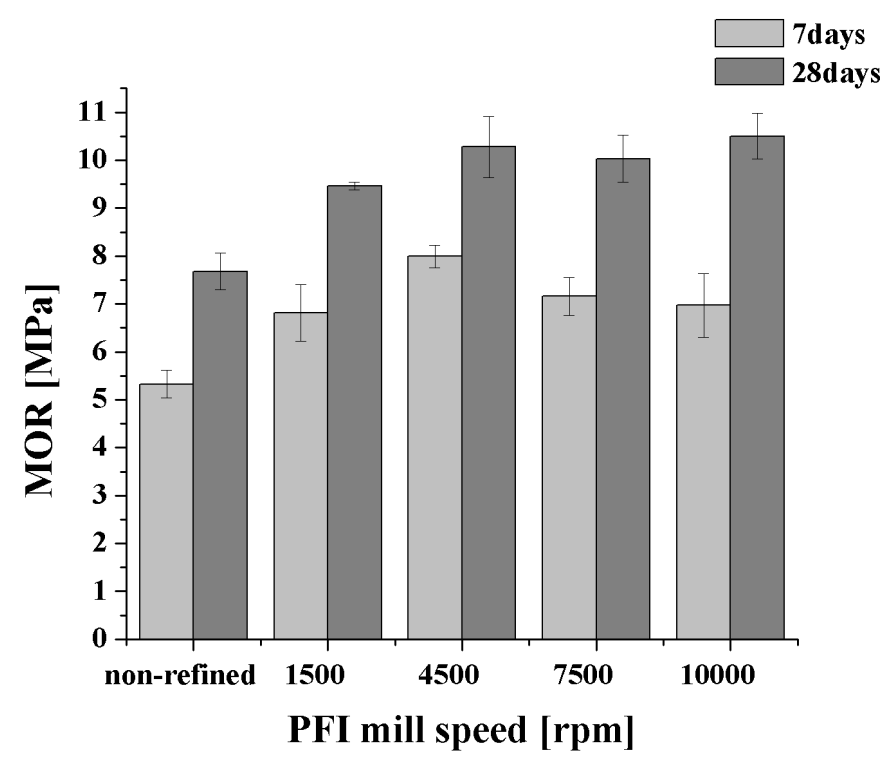

Figure 6. Flexural strength at 7 and 28 days of curing of composites reinforced with Guadua Angustifolia Kunth refined to different PFI mill speed.

\section{CONCLUSIONS}

The refining process causes effects on Guadua fibres favouring their plasticization and mechanical anchorage in the cement-based matrix. However, high refining degree also caused more damage to the filaments, with higher fibrillation and increase of fines causing a decrease in the mechanical performance of cement based materials.

Based on the results, the intensity or refining degree affects the cement-hydration reaction products; at first stage hydrated products increases exhibiting an optimal value between 4500 and 7000 revolutions per minute of refining. This study shows that refining to 4500 give the optimum mechanical and physical results.

\section{REFERENCES}

Agopyan, V., Savastano, H., John, V. M., \& Cincotto, M. A. (2005). Developments on vegetable fibre-cement based materials in São Paulo, Brazil: an overview. Cement and Concrete Composites, 27(5), 527-536.

https://doi.org/10.1016/j.cemconcomp.2004.09.004

Almeida, A. E. F. S., Tonoli, G. H. D., Santos, S. F., \& Savastano, H. (2013). Improved durability of vegetable fiber reinforced cement composite subject to accelerated carbonation at early age. Cement and Concrete Composites, 42, 49-58. https://doi.org/10.1016/j.cemconcomp.2013.05.001

Beg, M. D. H., \& Pickering, K. L. (2008). Mechanical performance of Kraft fibre reinforced polypropylene composites: Influence of fibre length, fibre beating and hygrothermal ageing. Composites Part A: Applied Science and Manufacturing, 39(11), 


\section{SCMT5}

Kingston University London, UK, 14-17 July 2019

1748-1755. https://doi.org/10.1016/j.compositesa.2008.08.003

Bissoli-Dalvi, M., Nico-Rodrigues, E. A., Alvarez, C. E. de, Saelzer Fuica, G. E., \& Montarroyos, D. C. G. (2016). The sustainability of the materials under the approach of ISMAS. Construction and Building Materials, 106, 357-363. https://doi.org/10.1016/j.conbuildmat.2015.12.030

Chen, Y., Wan, J., Zhang, X., Ma, Y., \& Wang, Y. (2012). Effect of beating on recycled properties of unbleached eucalyptus cellulose fiber. Carbohydrate Polymers, 87(1), 730 736. https://doi.org/10.1016/j.carbpol.2011.08.051

Ferreira, S. R., Silva, F. D. A., Lima, P. R. L., \& Toledo Filho, R. D. (2015). Effect of fiber treatments on the sisal fiber properties and fiber-matrix bond in cement based systems. Construction and Building Materials, 101, 730-740. https://doi.org/10.1016/j.conbuildmat.2015.10.120

Filho, J. D. A. M., Silva, F. D. A., \& Toledo Filho, R. D. (2013). Degradation kinetics and aging mechanisms on sisal fiber cement composite systems. Cement and Concrete Composites, 40, 30-39. https://doi.org/10.1016/j.cemconcomp.2013.04.003

Gao, W., Xiang, Z., Chen, K., Yang, R., \& Yang, F. (2015). Effect of depth beating on the fiber properties and ezymatic saccharification efficiency of softwood kraft pulp. Carbohydrate Polymers, 127, 400-406.

Gharehkhani, S., Sadeghinezhad, E., Kazi, S. N., Yarmand, H., Badarudin, A., Safaei, M. R., \& Zubir, M. N. M. (2015). Basic effects of pulp refining on fiber properties-A review. Carbohydrate Polymers, 115, 785-803. https://doi.org/10.1016/J.CARBPOL.2014.08.047

Indraratna, B., Chu, J., Rujikiatkamjorn, C., de Rezende, L. R., Camapum-de-Carvalho, J., \& Palmeira, E. M. (2015). Ground Improvement Case Histories. Ground Improvement Case Histories. Elsevier. https://doi.org/10.1016/B978-0-08-100698-6.00016-7

Jones, B. W., Venditti, R., Park, S., Jameel, H., \& Koo, B. (2013). Enhancement in enzymatic hydrolysis by mechanical refining for pretreated hardwood lignocellulosics. Bioresource Technology, 147, 353-360. https://doi.org/10.1016/j.biortech.2013.08.030

Juarez, C. A., Fajardo, G., Monroy, S., Duran-Herrera, A., Valdez, P., \& Magniont, C. (2015). Comparative study between natural and PVA fibers to reduce plastic shrinkage cracking in cement-based composite. Construction and Building Materials, 91, 164-170. https://doi.org/10.1016/j.conbuildmat.2015.05.028

Luo, X., \& Zhu J.Y. (2011). Effects of drying-induced fiber hornification on enzymatic saccharification of lignocelluloses. Enzyme and Microbial Technology, 48, 92-99.

Mohamad Bohari, A. A., Skitmore, M., Xia, B., Teo, M., Zhang, X., \& Adham, K. N. (2015). The path towards greening the Malaysian construction industry. Renewable and Sustainable Energy Reviews, 52, 1742-1748. https://doi.org/10.1016/j.rser.2015.07.148

Mohan, T. P., \& Kanny, K. (2012). Chemical treatment of sisal fiber using alkali and clay 


\section{SCMT5}

Kingston University London, UK, 14-17 July 2019

method. Composites Part A: Applied Science and Manufacturing, 43(11), 1989-1998. https://doi.org/10.1016/j.compositesa.2012.07.012

Rusu, M., Mörseburg, K., Gregersen, Ø., Yamakawa, A., \& Liukkonen, S. (2011). Relation Between Fibre Flexibility and Cross Sectional Properties. BioResources, 6(1), 641-655. https://doi.org/10.15376/biores.6.1.641-655

Santos, S. F., Tonoli, G. H. D., Mejia, J. E. B., Fiorelli, J., \& Jr, H. S. (2015). Nonconventional cement-based composites reinforced with vegetable fibers : A review of strategies to improve durability, 65(317).

Sawsen, C., Fouzia, K., Mohamed, B., \& Moussa, G. (2015). Effect of flax fibers treatments on the rheological and the mechanical behavior of a cement composite. Construction and Building Materials, 79, 229-235. https://doi.org/10.1016/j.conbuildmat.2014.12.091

Segal, L. ., Jr Creely, J., Martin, A. E. J., \& Conrad, C. M. (1959). An Empirical Method for Estimating the Degree of Crystallinity of Native Cellulose Using the X-Ray Diffractometer. Textile Research Journal, 29(10), 786-794. https://doi.org/10.1177/004051755902901003

Todd, J. A., Crawley, D., Geissler, S., \& Lindsey, G. (2001). Comparative assessment of environmental performance tools and the role of the Green Building Challenge. Building Research \& Information, 29(5), 324-335. https://doi.org/10.1080/09613210110064268

Tonoli, G. H. D., Belgacem, M. N., Siqueira, G., Bras, J., Savastano, H., \& Rocco Lahr, F. A. (2013). Processing and dimensional changes of cement based composites reinforced with surface-treated cellulose fibres. Cement and Concrete Composites, 37(1), 68-75. https://doi.org/10.1016/j.cemconcomp.2012.12.004

Tonoli, G. H. D., Rodrigues Filho, U. P., Savastano, H., Bras, J., Belgacem, M. N., \& Rocco Lahr, F. A. (2009). Cellulose modified fibres in cement based composites. Composites Part A: Applied Science and Manufacturing, 40(12), 2046-2053. https://doi.org/10.1016/j.compositesa.2009.09.016

Tonoli, G. H. D., Teixeira, E. M., Corrêa, A. C., Marconcini, J. M., Caixeta, L. A., PereiraDa-Silva, M. A., \& Mattoso, L. H. C. (2012). Cellulose micro/nanofibres from Eucalyptus kraft pulp: Preparation and properties. Carbohydrate Polymers, 89(1), 80-88. https://doi.org/10.1016/j.carbpol.2012.02.052

Wai, N. N., Nanko, H., \& Murakami, K. (1985). A morphological study on the behavior of bamboo pulp fibers in the beating process. Wood Science and Technology, 19(3), 211222. https://doi.org/10.1007/BF00392050

Yuan, L., Wan, J., Ma, Y., Wang, Y., Huang, M., \& Chen, Y. (2013). The content of different hydrogen bond models and crystal structure of eucalyptus fibers during beating. BioResources, 8(1), 717-734. 